13. Bank W, Chance B. An oxidative defect in metabolic myopathies: diagnostic by non-invasive tissue oximetry. Ann Neurol 1994;36:830-837.

14. Abe K, Matsuo Y, Kadekawa J, Inoue S, Yanagihara T. Measurement of tissue oxygen consumption in patients with mitochondrial myopathy by non-invasive tissue oximetry. Neurology 1997;49:837-841.

15. Van Beekvelt MC, Colier WN, Wevers RA, Van Engelen BG. Quantitative measurement of oxygen consumption and forearm blood flow in patients with mitochondrial myopathies. Adv Exp Med Biol 1999;471:313-319.

16. De Stefano N, Argov Z, Matthews PM, Karpati G, Arnold DL. Impairment of muscle mitochondrial oxidative metabolism in McArdle's disease. Muscle Nerve 1996;19:764-769.
17. Vissing J, Lewis SF, Galbo H, Haller RG. Effect of deficient muscular glycogenolysis on extramuscular fuel production in exercise. J Appl Physiol 1992;72:1773-1779.

18. Bruno C, Bado M, Minetti C, Cordone G. Forearm semi-ischemic exercise test in pediatric patients. J Child Neurol 1998;13: $288-290$.

19. Vissing J, Salamon MB, Arlien-Søborg P, et al. A new mitochondrial tRNA ${ }^{\mathrm{Met}}$ gene mutation in a patient with dystrophic muscle and exercise intolerance. Neurology 1998;50:18751878.

20. Wibrand F, Ravn K, Schwartz M, Rosenberg T, Horn N, Vissing J. Multisystem disorder associated with a missense mutation in the mitochondrial cytochrome $b$ gene. Ann Neurol 2001;50:540-543.
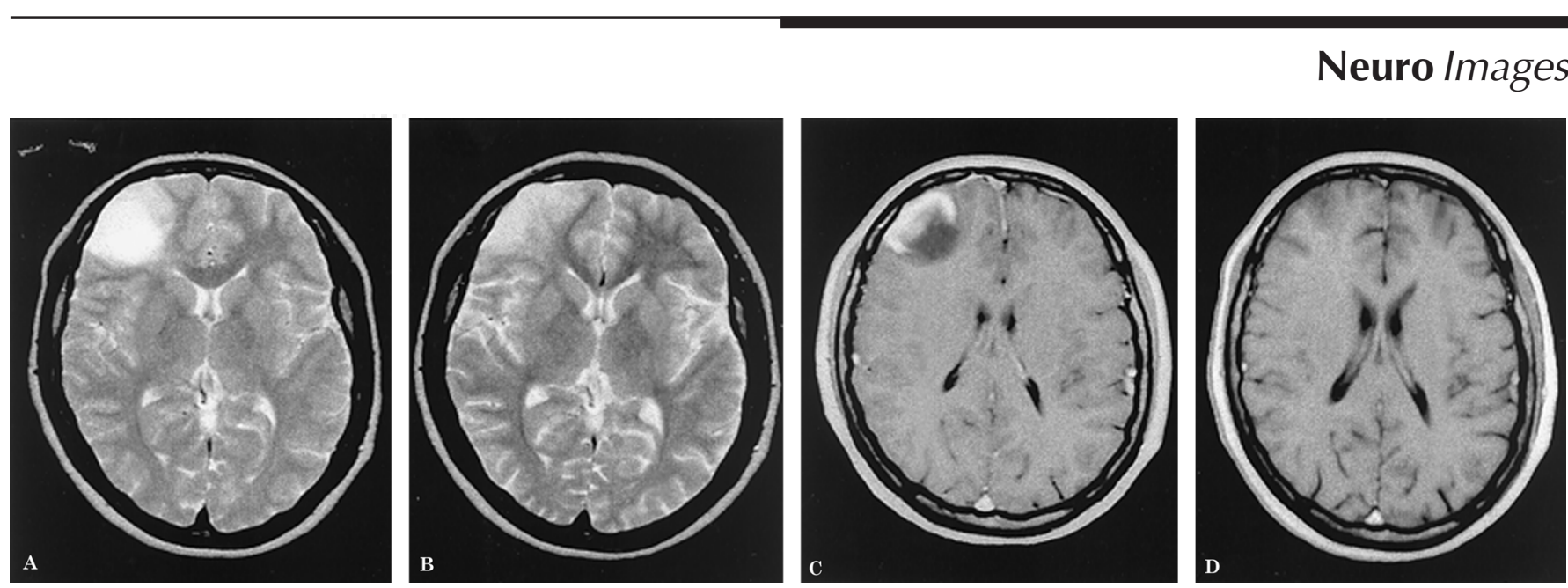

Figure. T2-weighted (A and B) and enhanced T1-weighted (C and D) axial MRI. MRI from July 1996, performed a few days after a generalized seizure, shows a gadolinium-enhancing right frontal lesion (A and C). MRI from September 1996 shows a marked regression of the lesion with complete disappearance of the cortical area of contrast enhancement (B and D).

\section{Seizure-related contrast enhancement of a ganglioglioma}

F. Laigle, MD, N. Martin-Duverneuil, MD, A. Carpentier, MD, K. Hoang-Xuan, MD, J.Y. Delattre, PhD, Paris, France

A 41-year-old woman presented with a generalized convulsive seizure. MRI showed a gadolinium-enhancing right frontal mass (figure, A and C). Because her clinical examination was normal, she was treated with sodium valproate and followed closely. Two months later, a follow-up MRI showed a remarkable spontaneous improvement (see the figure, B and D). Subsequently, she had convulsive status epilepticus and a repeated MRI demonstrated the reappearance of the contrast-enhancing mass. Biopsy demonstrated a ganglioglioma. The correlation between seizures and the spontaneous evolution of the mass suggested that seizures induced reversible MRI abnormalities. ${ }^{1,2}$ Such changes may be difficult to differentiate from tumor progression.

1. Quan D, Hackney DB, Pruitt AA, Lenkinski RE, Cecil KM. Transient MRI enhancement in a patient with seizures and previously resected glioma: use of MRS. Neurology 1999;53:211-213.

2. Yaffe K, Ferriero D, Barkovich AJ, Rowley H. Reversible MRI abnormalities following seizures. Neurology 1995;45:104-108. 


\section{Neurology}

\section{Seizure-related contrast enhancement of a ganglioglioma}

F. Laigle, N. Martin-Duverneuil, A. Carpentier, et al.

Neurology 2002;58;1538

DOI 10.1212/WNL.58.10.1538

\section{This information is current as of May 28, 2002}

\section{Updated Information \& Services}

\section{References}

Subspecialty Collections

Permissions \& Licensing

Reprints

\section{including high resolution figures, can be found at:} http://n.neurology.org/content/58/10/1538.full

This article cites 2 articles, 2 of which you can access for free at: http://n.neurology.org/content/58/10/1538.full\#ref-list-1

This article, along with others on similar topics, appears in the following collection(s):

\section{MRI}

http://n.neurology.org/cgi/collection/mri

Primary brain tumor

http://n.neurology.org/cgi/collection/primary_brain_tumor

Information about reproducing this article in parts (figures,tables) or in its entirety can be found online at:

http://www.neurology.org/about/about_the_journal\#permissions

Information about ordering reprints can be found online:

http://n.neurology.org/subscribers/advertise

Neurology ${ }^{\circledR}$ is the official journal of the American Academy of Neurology. Published continuously since 1951, it is now a weekly with 48 issues per year. Copyright . All rights reserved. Print ISSN: 0028-3878.

Online ISSN: 1526-632X.

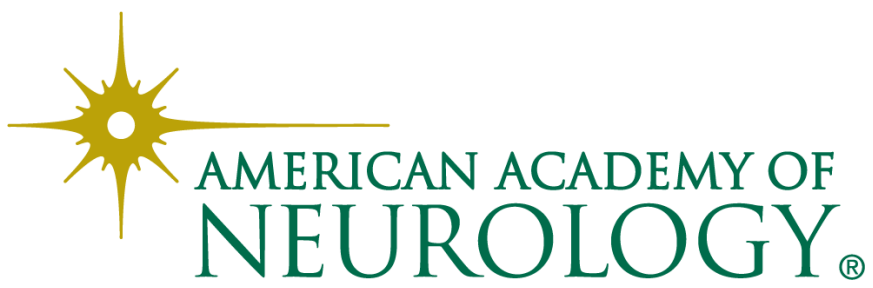

